\title{
A Covid-19-járvány gazdasági és munkaerőpiaci hatásai az elmúlt egy évben az Európai Unióban, különös tekintettel Magyarországra ${ }^{1}$
}

\section{The Economic and Labor Market Effects of the Covid- 19 Epidemic in the European Union over the Past Year, Especially in Hungary}

\author{
BÉRESNÉ B. ${ }^{1}$, MAKLÁRI E. ${ }^{2}$ \\ ${ }^{1}$ Debreceni Egyetem, Gazdaságtudományi Kar, Számviteli és Pénzügyi Intézet, Kontrolling Tanszék, \\ beresne.martha.bernadett@econ.unideb.hu \\ ${ }^{2}$ Debreceni Egyetem, Gazdaságtudományi Kar, Számviteli és Pénzügyi Intézet, Kontrolling Tanszék, \\ hallgató, eszter.maklari@gmail.com
}

\begin{abstract}
A 2020-as év elején megjelenő Covid-19 járvány világszerte nagy változásokat hozott minden ország életében. Tanulmányunkban - egy év távlatában - a koronavírusnak a gazdasági szektorokban megjelenő gazdasági és munkaerôpiaci hatásait és azok következményeit foglaljuk össze mind az Európai Unió, mind pedig hazánk vonatkozásában. A járványügyi intézkedések hatására bizonyos szektorok szerepe visszaszorult, míg más ágazatok hatalmas fejlődésen mentek keresztül. A távmunka elterjedése, a turizmus, a vendéglátás és a szórakoztatóipar hanyatlása a lakosság magatartásának a megváltozását eredményezte. A pandémia idôszakában bekövetkezett változások a vagyoni egyenlötlenségek további növekedéséhez vezettek. A fogyasztók értékrendjének és jövedelmi helyzetének az átalakulása a nemzetgazdaság valamennyi ágazatában érezteti hatását. Felmerül a kérdés: képesek vagyunk-e az elmúlt idôszakban bekövetkezett társadalmi-gazdasági változások által felszínre jött eseményekben a pozitív tényezőket is meglátni, és a negatív helyzetek, sérülékenységek, problémák mögé látni, azok valódi okát keresni és kezelni? A munkaerôpiacot milyen változások érintették az elmúlt évben, és ezekből kifolyóan milyen változásokkal számolhatunk a jövőben? Tanulmányunk ezen kérdések megválaszolásához a Covid-19-járvány gazdasági és munkaerőpiaci hatásainak bemutatásával nyújt segítséget.

Kulcsfogalmak: Covid-19, Európai Unió, Magyarország, társadalmi-, gazdasági hatások
\end{abstract}

The apparence of the Covid-19 pandemic at the beginning of 2020 affected all countries in the world, entailing major changes in everyday life. In our study - in a one year perspective - we summerize the economic and labor

\footnotetext{
1 „AZ INNOVÁCIÓS ÉS TECHNOLÓGIAI MINISZTÉRIUM ÚNKP-20-1 KÓDSZÁMÚ ÚJ NEMZETI KIVÁLÓSÁG PROGRAMJÁNAK A NEMZETI KUTATÁSI, FEJLESZTÉSI ÉS INNOVÁCIÓS ALAPBÓL FINANSZÍROZOTT

SZAKMAI TÁMOGATÁSÁVAL KÉSZÜLT."

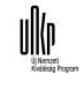


market effects of the Covid-19 pandemic on various economic sectors and their consequences for the European Union and Hungary. As a result of the pandemic restrictions the role of some sectors were decreasing considerably, while on the other hand the other sectors emerged and underwent a significant improvement. The growing trend of working from home, as well as the decline of the tourism, the catering service and the entertainment industry has led to a change in the behavior of the population. Changes during the pandemic period led to an increase in wealth inequalities. The transformation of consumers' values and income situation is having an huge impact on all sectors of the national economy. The question arises: are we able to see the positive factors in the events brought about by the socio-economic changes that have taken place in the recent period, and to see behind the negative situations, vulnerabilities, problems, to find and deal with their real cause? What changes have affected the labor market in the last year, and what changes can we expect in the future as a result? Our study will help answer these questions by presenting the economic and labor market impacts of the Covid-19 epidemic.

Keywords: Covid-19, European Union, Hungary, socio-economic impacts

\section{Bevezetés}

A globalizáció és a hálózatosodás korát éljük. Gazdasági szempontból országokat átívelő infrastrukturális hálózatokon keresztül egy ország több más országgal áll nemcsak kereskedelmi, hanem gazdasági, sőt kulturális kapcsolatban. Éppen ezért a 2020 tavaszán megjelenő Covid-19járvány szinte a világ minden pontjára elért, és ezáltal nemzetgazdaságok társadalmi, gazdasági életében eltérő módon, de átalakulási folyamatokat indított el. A pandémia rámutatott arra, hogy a világunkban minden mindennel összefüggésben van. [5] A hétköznapi életben bekövetkezett életviteli, munkavégzési, kommunikációs, stb. folyamatok változásait, a korlátozásokat bizonyos országok rugalmasabban, míg más nemzetek nehezebben tudták kezelni. Hazai vonatkozásban pl. a legtöbb új vírus fertőzöttet a nagyvárosokban regisztrálták, azonban a globalizációnak köszönhető gyors népességmozgás hatására a pandémia gyorsan terjedt más földrajzi helyekre is. A fertőzés kockázatát a fizikai távolság helyett elsősorban a megbetegedett személyek utazási szokásai határozták meg, hiszen sokan a felhívások ellenére sem akartak változtatni szokásikon, egészen a korlátozások életbe lépéséig. [20]

Célunk, hogy tanulmányunkban bemutassuk a Covid-19-járványnak az Európai Unió és hazánk munkaerőpiacán megjelenő azon hatásait, amelyek a munkaadók és alkalmazottainak mindennapjaiba a legnagyobb változást okozták. Emellett kitérünk a nemzetgazdaságok különböző szektoraiban a 2020-as évben bekövetkezett gazdasági átalakulási folyamatokra.

\section{A Covid-19-járvány hatása a munkaerőpiacra}

A 2020 tavaszán megjelenő Covid-19-járvány az egész világ múködését megváltoztatta, így az emberek életmódjára is jelentős hatást gyakorolt. A társas érintkezések csökkentése érdekében egyre több vállalat vezette be a távmunkavégzést, illetve a home office-t. A 2002-ben alárt távmunkáról szóló európai keretmegállapodás szerint a távmunkavégzés „olyan munkaszervezési és/vagy munkavégzési forma, mely a számítástechnikát egy munkaviszony keretei között veszi igénybe, illetve ahol a munkát, mely a munkaadó telephelyén is végezhető lenne, rendszeresen attól távol végzik". Herdon István tanulmányában a home office-t, másnéven otthoni munkavégzést a következőképpen definiálta: a home office „a munkáltató telephelyétől elkülönült 
helyen - általában a munkavállaló otthonában - rendszertelenül vagy nem rendszeresen folytatott tevékenység”. [9] A táv-, valamint az otthoni munkavégzésre vonatkozó szabályok között lényeges különbségeket fedezhetünk fel. A távmunkavégzés munkaszerződésben meghatározott foglalkoztatási mód, míg a home office-ban történő munkavégzésre a munkaadó egyoldalúan is kötelezheti a munkavállalót. A távmunkavégzés esetén a munkavállaló és a munkaadó által elfogadott munkaszerződés tartalmazza a munkavégzés helyét, ezzel szemben a home office-ban történő foglalkoztatás esetén a munkavállaló maga döntheti el, hogy hol látja el feladatait. Míg a távmunkát az alkalmazott meghatározott rendszerességgel végzi, addig az otthoni munkavégzés csupán a munkaidő kisebb részét teszi ki. [3]

Az EUROFOUND felmérése szerint 2020-ban az Európai Unió 27 tagállamában a munkavállalók 1/3-a (33,7\%) kizárólag otthonról végzett munkát (heti 38,9 órában), 14,2\%-a a munkaidő felét otthonában és felét pedig a munkáltató által biztosított irodában felváltva végezte, míg 52,1\%-uk otthonán kívül dolgozott (a munkáltató telephelyén vagy egyéb külső helyszíneken). Az otthonról dolgozók 2020-as évi aránya (33,7\%) meglehetősen túlszárnyalja az előző évek értékeit (1. táblázat), melyből erősen érezhető a Covid-19-járvány munkavégzés területén történt módosító hatása. [1]

\begin{tabular}{|c|c|}
\hline Évek & Az otthonról dolgozó munkavállalók aránya az Európai Unió 27 tagállamában \\
\hline 2011 & $11,4 \%$ \\
\hline 2015 & $12,9 \%$ \\
\hline 2019 & $14,3 \%$ \\
\hline 2020 & $20,6 \%$ \\
\hline
\end{tabular}

1. táblázat: Az otthonról dolgozó munkavállalók aránya az Európai Unió 27 tagállamában Forrás: [7] adatai alapján saját szerkesztés

Az EUROFOUND kutatási eredményei alapján az otthoni munkavégzés szoros korrelációban áll az iskolai végzettség szintjével. A felsőfokú végzettséggel rendelkező munkavállalók 74\%-a, a középfokú képesítéssel rendelkezők 34\%-a, míg az általános iskolát végzettek csupán 14\%-a dolgozott 2020-ban a munkahelyén kívül. Leginkább az oktatási tevékenységet végzők (több, mint 60\%), a pénzügyi (50-60\%) és a közigazgatási (40-50\%) területeken dolgozók végeztek távmunkát, illetve dolgoztak home office-ban. Azonban az otthoni- és a távmunkavégzés előfordult ipari, építkezési, mezőgazdasági, szállítási, kereskedelmi és egészségügyi területeken is. A nemek arányát tekintve több nő dolgozott otthon, mint férfi. A távmunka és a home office a 65 évnél idősebb munkavállalóknál volt a legnépszerúbb, második helyen a 15-29 év közötti korosztály tagjai álltak, őket követte a 30-49 év közötti korosztály. A legkevesebb munkahelyén kívül dolgozó munkavállaló az 50-64 év közötti korosztály tagjai közül került ki. Meglepő, hogy magasabb volt azoknak a távmunkavállalóknak és home office-ban dolgozóknak a száma, akiknek nem volt eltartott gyermeke. A kizárólag a munkahelyen kívül dolgozók száma tagállamonként jelentősen eltért. Horvátországban, Lengyelországban, Szlovákiában, Bulgáriában és Magyarországon a munkavállalóknak körülbelül 1/5-e, Franciaországban, Spanyolországban, Olaszországban, Írországban a foglalkoztatottaknak több, mint 40\%-a, míg Belgiumban több, mint 50\%-a végzett távmunkát vagy dolgozott home office-ban. [1] 
$\mathrm{Az}$ otthoni- és a távmunkavégzés elterjedése mellett számos változás figyelhető meg a munkaerőpiacon. A koronavírus hatására egyre több munkavállalót alkalmaztak részmunkaidőben. 2020 első negyedévében 2019 utolsó negyedévéhez képest az Európai Unióban átlagosan 2,8\%-kal csökkent a ledolgozott munkaórák száma. 2020 első negyedévében az előző negyedévéhez képest a legnagyobb változás Olaszországban volt tapasztalható, ott 9,7\%kal, míg Szlovákiában 8,7\%-kal, Görögországban és Ausztriában 7,9\%-kal csökkent a főállásban ledolgozott összes tényleges munkaórák száma. Finnország kivételt képez az általános tendencia alól, ott 0,2\%-os növekedés történt. A különböző szektorokban eltérő mértékben jelentkezett a munkaidőcsökkenés. A kereskedelem, a vendéglátás és az építészet területén voltak érezhetőek leginkább a Covid-19- járvány hatásai. Az ezekben a szférákban dolgozó válaszadók 52\%-ának, a szállítás területén a megkérdezett munkavállalók 48\%-ának, az iparban a 47\%-ának, a szolgáltatások és az oktatás területén a 36\%-ának, a pénzügyi szférában a 30\%-ának, a mezőgazdaság szektorában a 24\%-ának, az egészségügyben dolgozóknál a 23\%-ának, az állami szférában a 21\%-ának csökkent a foglalkoztatási ideje. [1]

A részmunkaidőben történő foglalkoztatás nőknél sokkal gyakoribbá vált, mint a férfiaknál. A koronavírus hatására a nők munkaideje átlagosan 5,2\%-kal, míg a férfiaké 4,9\%-kal csökkent. Olaszországban, Szlovákiában, Görögországban, Ausztriában és Portugáliában különösen nagy hatással volt a nők életére a koronavírus megjelenése. Olaszországban 10,3\%-kal, Szlovákiában 10,2\%-kal, Görögországban 8,3\%-kal, Ausztriában 7,8\%-kal, Portugáliában 6,3\%-kal csökkent átlagosan a nők munkaideje. A férfiak foglalkoztatási ideje Olaszországban (-9,3\%), Ausztriában (-8,0\%), Magyarországon (-7,9\%), valamint Máltán és Szlovákiában (egyaránt -7,6\%) csökkent a legnagyobb mértékben. [6]

Szintén az EUROFOUND kérdőíves felmérése szerint a Covid-19-járvány megjelenését követően a válaszadók 10\%-a hagyta el a munkaerőpiacot. Ezek 80\%-a munkanélkülivé, míg 20\%-a inaktívvá vált. Az utóbbi csoportba tartozók nyugdíjba mentek, megbetegedtek, tanulók vagy háztartásbeliek lettek. Így együttesen a munkavállalók 10\%-a veszítette el vagy hagyta el önkéntesen állását. Mindössze 3\% azoknak az aránya, akik a Covid-19-járvány térhódítását követően léptek be a munkaerőpiacra. [1] A koronavírus leginkább a spanyol, a ciprusi és a görög munkaerőpiacon éreztette legjobban a hatását 2020-ban. Spanyolországban a válaszadó munkavállalók 16\%-a, Cipruson 15\%-a, Görögországban 14\%-a vesztette el állásását. Magyarországon és Lettországban a megkérdezettek 12\%-a, Bulgáriában, Franciaországban, Portugáliában, Romániában, Írországban, Litvániában, Lengyelországban és Horvátországban a válaszadók 9\%-a, Finnországban, Dániában és Luxemburgban 8\%-a, Ausztriában, Észtországban, Belgiumban, Szlovéniában és Olaszországban 7\%-a, Németországban 5\%-a, Csehországban, Szlovákiában, Máltán és Hollandiában 4\%-a, Svédországban 3\%-a a megkérdezetteknek a Covid19-járvány térhódítását követően munkanélkülivé vált. A nemek arányát tekintve kis különbség fedezhető fel. Átlagosan a nők 9\%-a, míg a férfiak 8\%-a vált munkanélkülivé az Európai Unióban. Különösen a 18-34 év közötti munkavállalók foglalkoztatási helyzetét változtatta meg a járvány megjelenése, a csoporton belül a nők 11\%-a, a férfiak 9\%-a vesztette el a munkahelyét. A fiatal korosztály után az 50 év feletti munkavállalók szenvedték meg legjobban a járvány elterjedését. Az ebbe a korosztályba tartozó nők és férfiak egyaránt $8 \%$-a vált munkanélkülivé. A legkevésbé a 35-49 év közötti korosztály tagjait érintette a járvány munkaügyi szempontból. Az idetartozó nők 
9\%-ának, férfiak 6\%-ának változott meg a foglalkoztatási helyzete a járványügyi helyzet hatására. A kutatási eredményekből kiderül, hogy az Európai Unióban több vállalkozó veszítette el munkahelyét, mint alkalmazott. A középfokú vagy annál alacsonyabb végzettségúek között jellemzően több a munkanélkülivé vált személyek aránya, mint a felsőfokú végzettséggel rendelkezők körében. [1]

A Covid-19-járvány megjelenése a magyar munkaerőpiacon is hatalmas változásokat idézett elő. A Covid-19-járvány térhódítása előtt Magyarországon az európai államokhoz képest alacsonyabb volt a távmunkát végzők foglalkoztatottakhoz viszonyított aránya (6\%), azonban ez a munkavégzési forma 2018-ban pl. Hollandiában (36\%) és Svédországban (35\%) már meghatározó módon volt jelen. [16] Az 1. ábra alapján látható, hogy Magyarországon míg 2019 első negyedévében 28.642 fő végzett távmunkát, addig 2020 hasonló időszakában már 83.596 fő (190\%-os növekedés). A legmagasabb mért érték 2020 áprilisa és júniusa között volt (292.155 fő). [12] A 2020-as év nyarára ez az érték csökkent, majd ősztől egy újabb növekedés indult meg, és vélhetően 2021 tavaszán a 2020-as év legmagasabb értékét is túlszárnyalhatja a távmunkát végzők száma köszönhetően a vírus 3. hullámának. Az utóbbi csoportba tartozók számának alakulásával a munkanélküliek száma is szinte együtt mozgott. Az elmúlt évben szintén az áprilisi és a júniusi időszak között regisztrálták a legtöbb munka nélkül lévőt (214.200 fő) országos szinten.

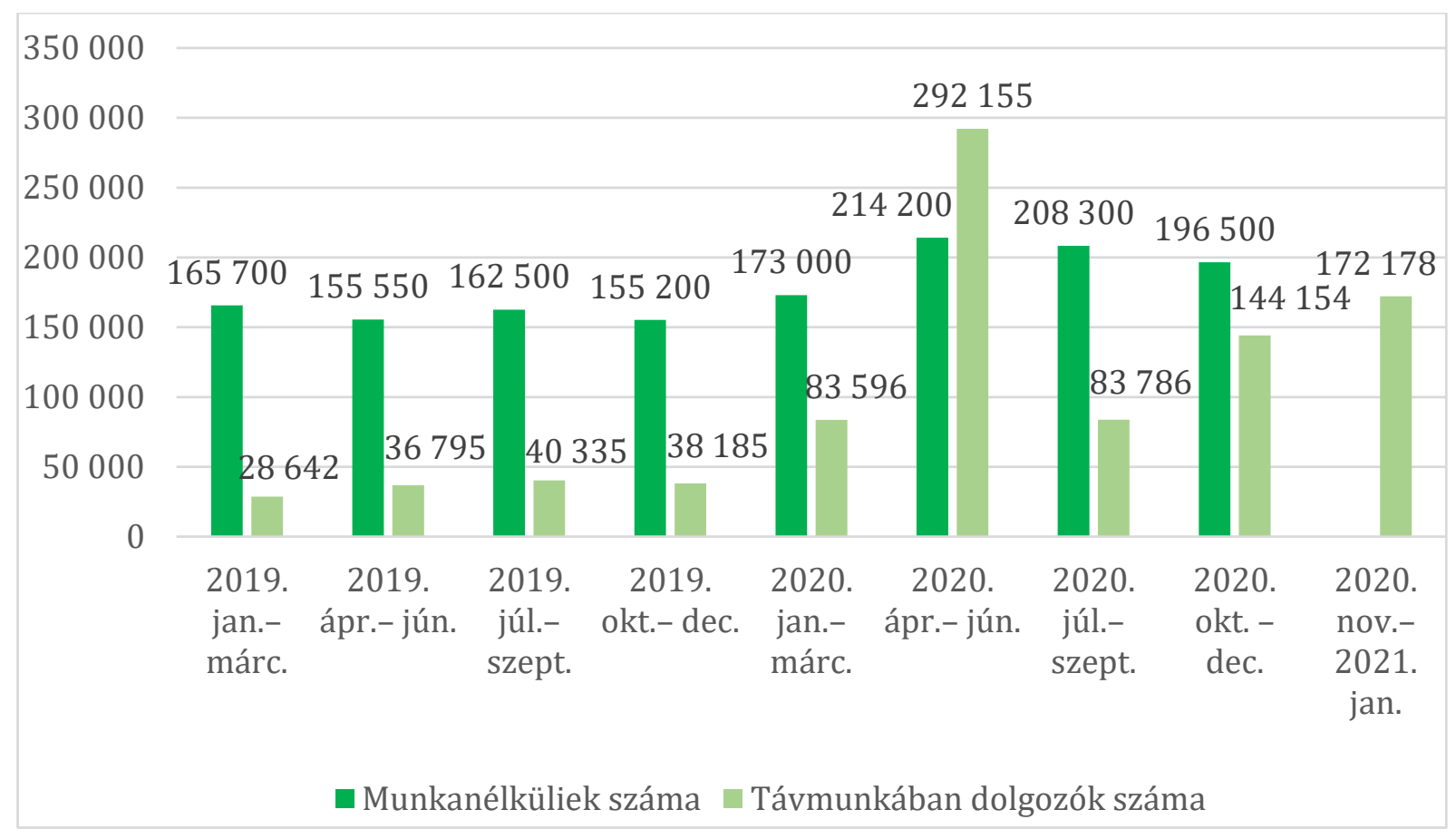

1. ábra: A munkanélküliek és a távmunkát végzők számának alakulása Magyarországon 2019-2021 között (fö)

Forrás: [12], [13] adatai alapján saját szerkesztés

Magyarország nagyrégióit vizsgálva elmondható, hogy 2020 második negyedévében a munkanélküliek 47\%-át - területi kiterjedéséből és gazdaságilag aktív népességéből adódóan az Alföld és Észak nagyrégióban regisztrálták, aminek eredményeként a munkanélküliségi ráta értéke 5,8\% lett. A lakosság második legnagyobb számú foglalkoztatottal és gazdaságilag aktív 
népességgel rendelkező nagyrégiója a közép-magyarországi nagyrégió, ahol ezen időszak alatt a munkanélküliségi ráta 3,8\%-os értékével kisebb volt az előzőhöz képest, azonban itt egy fő munkanélkülire jóval több, 26 fő foglalkoztatott jutott. [13] Czirfusz Márton tanulmányában megállapította, hogy a közfoglalkoztatási munkahelyek jobban tudtak alkalmazkodni a Covid-19járvány okozta új munkaerőpiaci helyzethez, ezért leginkább a magas közfoglalkoztatotti aránnyal rendelkező települések voltak képesek a Magyarországon belüli térbeli munkamegosztásban a koronavírus-járvány előtti helyzetüket fenntartani. [4] A munkanélküliségi ráta értéke a dunántúli nagyrégióban a 4,1\%-os nagyságával meghaladta a közép-magyarországi értéket annak ellenére, hogy itt kevesebb a gazdaságilag aktív népesség száma. Ebben a térségben egy fó munkanélkülire 23 fő foglalkoztatott esett. [13] Ezekből az adatokból le lehet vonni azt az általános következtetést, hogy a járvány hatására a munkanélküliség növekedése az ország azon területét érintette a legkevésbé, ahol átlagosan véve magasabb a foglalkoztattak képzettségi szintje. Ebből kifolyólag ők rugalmasan tudtak reagálni a változásokra a home office, illetve a távmunka bevezetésének segítségével. A munka világába, főleg a fizikai munkába való visszatérés nem egyszerű folyamat, a gazdasági változásokra lassabban tud reagálni, mint a távmunkát végzők számának változása.

A 2. ábra a munkanélküliek számát korcsoportonként ábrázolja országunkban a 2019-es és a 2020-as évre vonatkozóan.

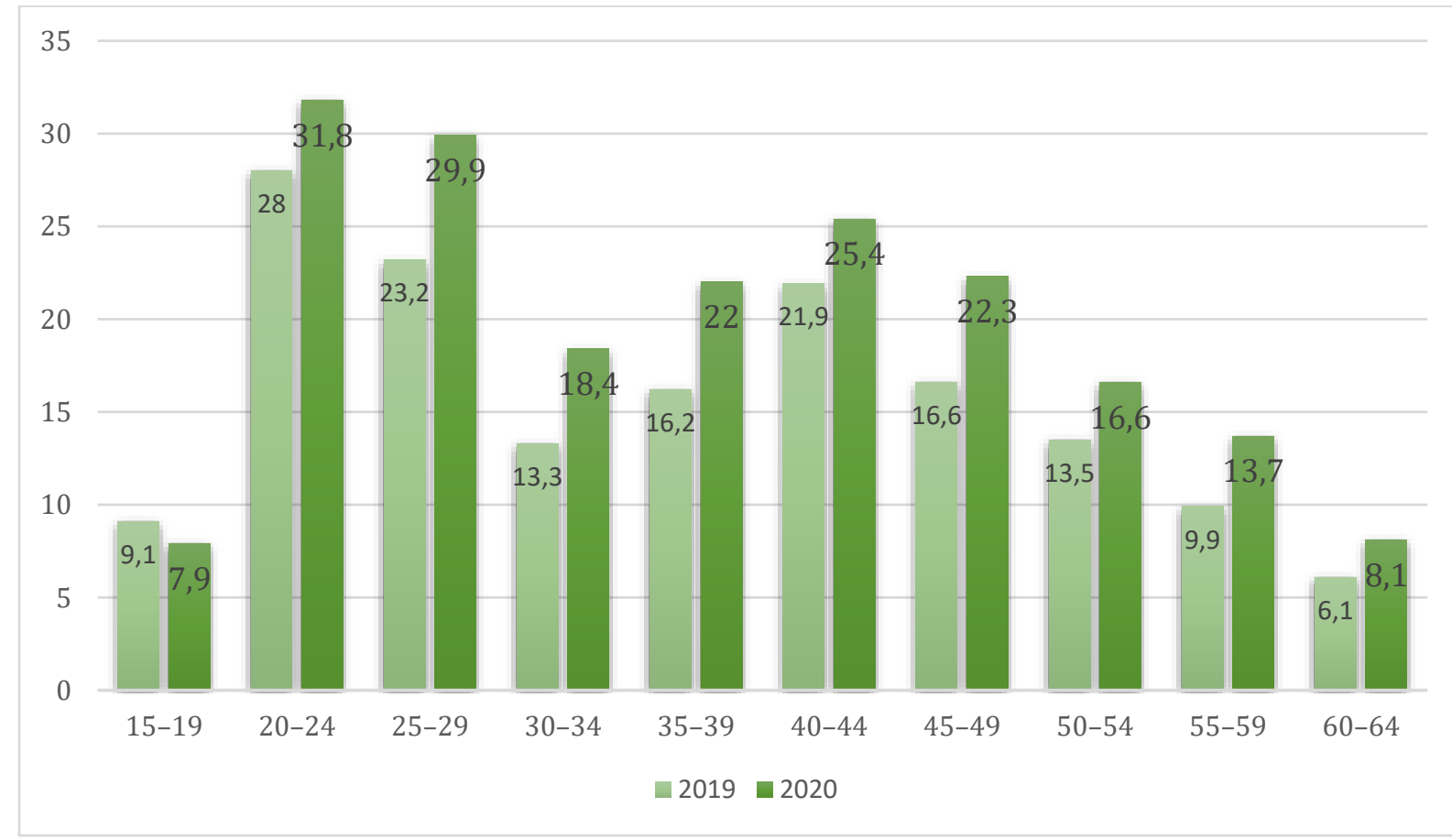

2. ábra: A munkanélküliek száma korcsoportok szerint Magyarországon a 2019-es és a 2020as évre vonatkozóan (ezer fö)

Forrás: [14] adatai alapján saját szerkesztés

Megfigyelhetjük, hogy 2020-ban a 15-19 éves korosztály kivételével minden korcsoportban jelentősen nőtt a munkanélküliek száma. A 20-24 éves korosztályban 3.800 fôvel, a 25-29 évesek közül 6.700 fővel, a 30-34 éves korcsoportban 5.100 fővel, a 35-39 éves korosztályba tartozók közül 5.800 fővel, a 40-44 évesek közül 3.500 fővel, a 45-49 éves korcsoportban 5.700 fővel, az 
50-54 éves korosztályban 3.100 fővel, az 55-59 évesek közül 3.800 fővel, a 60-64 éves korcsoportban 2.000 fővel több munkanélkülit regisztráltak 2020-ban, mint 2019-ben. Leginkább a 25-29 éves korosztály tagjainak foglalkoztatási helyzetét változtatta meg a járvány megjelenése. Őket követték a 35-39, majd a 45-49 évesek. A legkevésbé a 60-64 éves korcsoportba tartozók munkaerőpiaci helyzetét érintette a pandémia. [14]

A Központi Statisztikai Hivatal adatai alapján megállapítható, hogy 2019-ről 2020-ra a munkanélküli nők száma 1,28\%-kal, a férfiaké 1,21\%-kal nőtt. [14] A munkanélküliség, a távmunka és a home office elterjedése mellett országszerte jellemző költségcsökkentő intézkedés volt az alkalmazottak munkaidejének a csökkentése (2. táblázat). 2020 áprilisától folyamatosan nőtt a munkaidő-csökkentésben érintett munkavállalók száma. A legmagasabb számot 2020 júniusának végén érte el, ekkor több, mint 260 ezer alkalmazott dolgozott részmunkaidőben. Az utóbbi csoportba tartozók aránya Fejér megyében (4,3\%) és GyőrMoson-Sopron megyében (3,5\%) volt a legmagasabb. A legtöbb érintett személy a turizmusvendéglátás, a feldolgozóipar, a kereskedelem területén, az adminisztratív szolgáltatásnyújtás, az ingatlanügyek és a pénzügyi szolgáltatások területén dolgozott, így öket érintette a vírus hatására bekövetkezett munkaidö-csökkentés a legnagyobb mértékben. Majd a 26. héttől folyamatos csökkenés indult el, és a 40. héten már kevesebb részmunkaidőben dolgozó személy állt munkában, mint a 18. héten. [11]

\begin{tabular}{|c|c|}
\hline A 2020-as év hetei & $\begin{array}{c}\text { A munkaidő-csökkentésben érintett alkalmazottak } \\
\text { száma }\end{array}$ \\
\hline 18. hét (április 27. - május 3.) & 132.700 \\
\hline 25. hét (június 15. - június 21.) & 261.100 \\
\hline 40. hét (szeptember 28. - október 4.) & 123.000 \\
\hline
\end{tabular}

2. táblázat: A munkaidö-csökkentésben érintett alkalmazottak száma 2020-ban

Forrás: [11] adatai alapján saját szerkesztés

A 3. táblázatban tartalmazza összefoglalóan az Unióban és a hazánkban bekövetkezett munkaerőpiaci változásokat a 2020-as évben.

\begin{tabular}{|c|c|c|}
\hline Megnevezés & Európai Unió (27 tagállam) & Magyarország \\
\hline Távmunkát végzők (\%) & a munkavállalók 33,7\%-a & a munkavállalók 3,4\%-a \\
\hline $\begin{array}{l}\text { Home office-ban } \\
\text { dolgozók (\%) }\end{array}$ & a munkavállalók 14,2\%-a & a munkavállalók 5,3\%-a \\
\hline $\begin{array}{l}\text { A távmunka és a home } \\
\text { office végzése } \\
\text { korosztályok és nemek } \\
\text { szerint }\end{array}$ & $\begin{array}{l}\text { 1. hely: A } 65 \text { évnél idősebb } \\
\text { munkavállalók } \\
\text { 2. hely: A 15-29 év közötti } \\
\text { korosztály tagjai } \\
\text { 3. hely: A 30-49 év közötti } \\
\text { munkavállalók } \\
\text { 4. hely: A 50-64 év közötti } \\
\text { korosztály tagjai } \\
\text { A nemek arányát tekintve több } \\
\text { nő dolgozott otthon, mint férfi. }\end{array}$ & $\begin{array}{l}\text { Az otthoni munkavégzés a 25- } \\
44 \text { éves nők körében volt a } \\
\text { leggyakoribb. }\end{array}$ \\
\hline $\begin{array}{l}\text { Azoknak a szektoroknak } \\
\text { a megnevezése, } \\
\text { amelyekben a }\end{array}$ & $\begin{array}{l}\text { 1.Az oktatási tev.-et végzők } \\
\text { (több, mint } 60 \% \text { ) }\end{array}$ & $\begin{array}{l}\text { 1.Információ, kommunikáció } \\
(39,1 \%)\end{array}$ \\
\hline
\end{tabular}




\begin{tabular}{|c|c|c|}
\hline $\begin{array}{l}\text { távmunkavégzés } \\
\text { leginkább jellemző }\end{array}$ & $\begin{array}{l}\text { 2.A pénzügyi területen dolgozók } \\
\text { (50-60\%) } \\
\text { 3.A közigazgatásban dolgozók } \\
(40-50 \%)\end{array}$ & $\begin{array}{l}\text { 2.Tudományos és műszaki tev. } \\
(33,5 \%) \\
\text { 3.Pü-i szolgáltatás }(29,8 \%) \\
\text { 4.Oktatás }(21,4 \%) \\
\text { 5.Művészet, szabadidő }(14,2 \%)\end{array}$ \\
\hline $\begin{array}{c}\text { A ledolgozott } \\
\text { munkaórák számának } \\
\text { változása }\end{array}$ & $\begin{array}{l}\text { nők: }-5,2 \% \\
\text { férfiak: }-4,9 \%\end{array}$ & $\begin{array}{l}\text { nők: nincs adat } \\
\text { férfiak: }-7,9 \%\end{array}$ \\
\hline $\begin{array}{l}\text { A munkaidő- } \\
\text { csökkenésben leginkább } \\
\text { érintett szektorok }\end{array}$ & $\begin{array}{l}\text { 1.Kereskedelem, vendéglátás, } \\
\text { építészet }(52 \%) \\
\text { 2.Szállítás }(48 \%) \\
\text { 3.Iparban }(47 \%) \\
\text { 4.Szolg.-ok, oktatás }(36 \%) \\
\text { 5.Pénzügyi szféra }(30 \%) \\
\text { 6.Mezőgazdaság }(24 \%) \\
\text { 7.Egészségügy }(23 \%) \\
\text { 8.Állami szféra }(21 \%)\end{array}$ & $\begin{array}{l}\text { 1.Szálláshely-szolgáltatás, } \\
\text { vendéglátás }(11,8 \%) \\
\text { 2.Feldolgozóipar }(4,6 \%) \\
\text { 3.Kereskedelem }(4,1 \%) \\
\text { 4.Adminisztratív szolgáltatás } \\
(3,9 \%) \\
\text { 5.Ingatlanügyletek }(3,4 \%) \\
\text { 6.Pü-i szolgáltatás }(3,2 \%) \\
\text { 7.Egyéb szolg. }(2,5 \%) \\
\text { 8.Szállítás, raktározás }(2,3 \%) \\
\text { 9.Építőipar }(2,2 \%) \\
\text { 10.Művészet és szabadidő } \\
\text { (2,1\%), tudományos és műszaki } \\
\text { tevékenység }(2,1 \%) \\
\text { 11.Bányászat }(1,7 \%) \\
\text { 12.Információ és kommunikáció } \\
\text { (1,4\%) } \\
\text { 13.Humán eü-i, szociális ellátás } \\
\text { (1,2\%) } \\
\text { 14.Oktatás }(1,0 \%), \text { víz- és } \\
\text { hulladékgazdálkodás }(1,0 \%) \\
\text { 15.Mezőgazdaság }(0,9 \%) \\
\text { 16.Közigazgatás }(0,4 \%) \\
\text { 17.Energiaipar }(0,2 \%)\end{array}$ \\
\hline $\begin{array}{c}\begin{array}{c}\text { A munkaerőpiacon } \\
\text { lévők számának } \\
\text { alakulása }\end{array} \\
\end{array}$ & $\begin{array}{l}\text { Kilépők aránya: 10\% } \\
\text { Belépők aránya: 3\% }\end{array}$ & $\begin{array}{l}\text { Kilépők aránya: } 14 \% \\
\text { Belépők aránya: nincs adat }\end{array}$ \\
\hline $\begin{array}{c}\text { A pandémia } \\
\text { térhódításának hatására } \\
\text { munkanélkülivé vált } \\
\text { vállalkozók és } \\
\text { alkalmazottak } \\
\text { korosztályok és nemek } \\
\text { szerint }\end{array}$ & 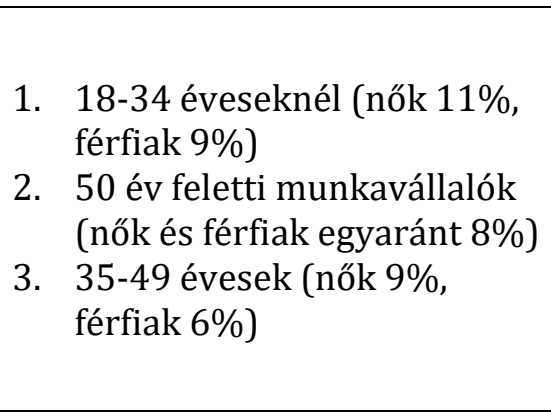 & $\begin{array}{ll}\text { 1. } & \text { 25-29 évesek (6700 fó) } \\
2 . & 35-39 \text { évesek (5800 fó) } \\
3 . & 45-49 \text { évesek (5700 fó) } \\
4 . & 30-34 \text { évesek (5100 fó) } \\
5 . & \text { 20-24 évesek és az 55-59 } \\
& \text { évesek (3800 fő) } \\
\text { 6. } & 40-44 \text { évesek (3500 fó) } \\
\text { 7. } & \text { 50-54 évesek (3100 fó) } \\
\text { 8. } & \text { 60-64 évesek (2000 fó) }\end{array}$ \\
\hline
\end{tabular}

3.táblázat: Az Európai Unió és Magyarország munkaerőpiaci helyzetében a Covid-19-járvány hatására bekövetkezett legföbb változások

Forrás: [1], [6], [11], [14] és [15] adatai alapján saját szerkesztés 


\section{A koronavírus hatása a különböző szektorok fejlődésére}

A Covid-19-járvány térhódításának következménye, hogy 2020 első három negyedévében az előző év azonos időszakához viszonyítva az Európai Unió gazdaságának hozzáadott értéke átlagosan 5,8\%-kal csökkent. Magyarországon 9,7\%-os visszaesés volt tapasztalható figyelembe véve az egyes ágazatok GDP előállításában játszott szektorok megoszlási arányait. A 4. táblázat szektorok szerinti bontásban mutatja be a 2019-es év adatihoz viszonyítva a 2020-as év első három negyedévének bruttó hozzáadott értékének volumenváltozását az Európai Unió országainak az átlagában és Magyarországon.

\begin{tabular}{|l|c|c|}
\hline \multirow{2}{*}{\multicolumn{1}{|c|}{ A szektor neve }} & \multicolumn{2}{c|}{ A bruttó hozzáadott érték változása (\%) } \\
\cline { 2 - 3 } & EU átlagában & Magyarországon \\
\hline Információ és kommunikáció & 0,2 & 4,5 \\
\hline Pénzügy és biztosítás & $-1,3$ & 3,6 \\
\hline Ingatlanügyletek & $-0,8$ & $-2,0$ \\
\hline Mezőgazdaság & $-1,1$ & $-2,5$ \\
\hline Közigazgatás, védelem, oktatás, egészségügy & $-2,8$ & $-18,8$ \\
\hline Nagy- és kiskereskedelem, szállítás, szállás & $-12,6$ & $-44,5$ \\
\hline Szakmai, tudományos és múszaki tevékenység & $-8,7$ & $-7,0$ \\
\hline Ipar & $-9,4$ & $-7,2$ \\
\hline Építőipar & $-5,9$ & $-11,7$ \\
\hline Művészet, szórakozás és szabadidő & -16 & $-11,2$ \\
\hline
\end{tabular}

4. táblázat: A bruttó hozzáadott érték volumenváltozása 2020 első három negyedévében 2019 hasonló időszakához képest az Európai Unió országainak átlagában és Magyarországon

Forrás: [10] és [8] adatai alapján saját számolás és szerkesztés

A Covid-19-járvány megjelenésének hatására a legtöbb ágazatban a termékek és a szolgáltatások iránt csökkent a kereslet. A vírus térhódítása csökkentette a szálláshely-szolgáltatás, a szállítás, a raktározás, az egészségügy, a szociális ellátás, az építőipar, a művészet, a szabadidő, az ipar, az üzleti szolgáltatások, az oktatás, a mezőgazdaság, a közigazgatás és az ingatlanügyek területének GDP-hez való hozzájárulását. A járvány csupán a kommunikációval, a pénzügyi szolgáltatásokkal foglalkozó vállalatok számára hozott pozitív változást hazánkban. A kommunikáció ágazatába tartozó vállalatok 4,5\%-kal, a pénzügyi szektor szolgáltatásai 3,6\%-kal növelték országunk GDPjét. Látható, hogy az EU-ban a járvány egyedül az infokommunikációs ágazat fejlődésére volt pozitív hatással. A pandémia legnagyobb vesztese a Közösségben a művészet, a szórakozás és a szabadidő területe volt, addig Magyarországon a kereskedelem, szállítás és szállás, mely 3,5-szer nagyobb veszteséget volt kénytelen elviselni, mint az EU-ban. Kiemelendő még az összehasonlításban a közigazgatás, a védelem, az oktatás és az egészségügy területe, mely területeken belül 6,7-szer rosszabbul teljesített hazánk. [10] és [8]

Hazánkban a munkanélkülivé vált és a részmunkaidőben alkalmazott munkavállalók egy részének jelentősen csökkent a jövedelme, mindamellett, hogy a maginfláció 2020. márciustól októberig az általános árszínvonalnál magasabb szinten (3,8-4,6\%) mozgott. A fogyasztói árak hazai drágulása uniós összehasonlításban kiemelkedőnek számított. A Közösségben 2,0\% feletti drágulást hazánk mellett csak a többi visegrádi országban és Romániában mértek, ugyanakkor Észtország és 
Írország mellett jellemzően a dél-európai tagállamokban mérséklődtek az árak. Összességében 0,8\% volt az infláció az Európai Unióban. Ezen folyamatok hatással voltak a kereskedelmi tevékenységet folytató üzletek forgalmának alakulására. Magyarországon, Csehországban és Lengyelországban egyaránt a ruha- és cipőipar forgalma esett a legnagyobb mértékben vissza. Az 5. táblázat a különböző üzlettípusok 2020-as évi forgalmának alakulását mutatja Magyarországra vonatkozóan. [17]

\begin{tabular}{|l|c|}
\hline \multicolumn{1}{|c|}{ Üzlet típusának megnevezése } & Forgalom alakulása (\%) \\
\hline Textil-, ruházat- és cipőboltok & $-20,73$ \\
\hline Autóipari üzemanyag-értékesítés & $-9,47$ \\
\hline Bútor- és elektronikai cikkboltok & $-19,67$ \\
\hline Nem élelmiszerüzletek (az üzemanyag-értékesítés kivételével) & $-0,41$ \\
\hline Elsősorban élelmiszer- és italboltok & 2,15 \\
\hline Gyártott áruk értékesítése nem szakosodott üzletekben & 2,46 \\
\hline $\begin{array}{l}\text { A kiskereskedelemi üzletek forgalma a gépjármü-üzemanyag } \\
\text { kivételével }\end{array}$ & 1,72 \\
\hline Használtáru üzletek & $-10,85$ \\
\hline $\begin{array}{l}\text { Könyvesboltok, számítástechnikai cikkek eladásával } \\
\text { foglalkozó üzletek }\end{array}$ & $-7,62$ \\
\hline $\begin{array}{l}\text { Gyógyszerészeti, gyógyászati termékek és kozmetikai cikkek } \\
\text { üzletei }\end{array}$ & 2,81 \\
\hline $\begin{array}{l}\text { Élelmiszerekre, italtermékekre és dohánytermékekre } \\
\text { szakosodott üzletek }\end{array}$ & 0,56 \\
\hline Élelmiszerboltok & 1,67 \\
\hline
\end{tabular}

5. táblázat: A különbözö üzlettípusok 2020-as forgalmának alakulása Magyarországra vonatkozóan Forrás: [17] adatai alapján saját szerkesztés

A 6. táblázat a különböző üzlettípusok 2020-as évi forgalmának alakulását mutatja Magyarországra, Lengyelországra, Csehországra és Romániára vonatkozóan.

\begin{tabular}{|l|c|c|c|c|}
\hline \multirow{2}{*}{ Üzlet típusának megnevezése } & \multicolumn{4}{|c|}{ Forgalom megjelenítése (\%) } \\
\cline { 2 - 5 } & Magyarország & Lengyelország & Csehország & Románia \\
\hline Textil-, ruházat- és cipőbolt & $-20,73$ & $-9,90$ & $-18,00$ & 4,11 \\
\hline Bútor- és elektronikai cikkbolt & $-19,67$ & $-2,43$ & 4,76 & 8,61 \\
\hline $\begin{array}{l}\text { Könyvesboltok, számítástechni-kai } \\
\text { cikkek eladásával foglalkozó üzletek }\end{array}$ & $-7,62$ & $-1,90$ & $-6,44$ & $\begin{array}{c}\text { nincs } \\
\text { adat }\end{array}$ \\
\hline $\begin{array}{l}\text { Gyógyszerészeti, gyógyászati } \\
\text { termékek és kozmetikai cikkek } \\
\text { üzletei }\end{array}$ & 2,81 & $-8,57$ & 4,44 & 7,84 \\
\hline $\begin{array}{l}\text { Élelmiszerekre, ital-, és dohány- } \\
\text { termékekre szakosodott üzletek }\end{array}$ & 0,56 & 4,63 & $-3,99$ & 7,55 \\
\hline
\end{tabular}

6. táblázat: A különböző üzlettípusok 2020-as forgalmának alakulása Forrás: [17] adatai alapján saját szerkesztés 
A 6. táblázatban szereplő négy európai országot vizsgálva megállapíthatjuk, hogy a textil-, a ruházat- és a cipőboltok, valamint a könyvesboltok és a számítástechnikai cikkek eladásával foglalkozó üzletek forgalma a legnagyobb mértékben Magyarországon és Csehországban esett vissza. A bútor- és elektronikai cikkboltok termékeinek eladását tekintve Magyarország, gyógyszerészeti, gyógyászati termékek és kozmetikai cikkek értékesítésének területén Lengyelország a vizsgált országok közül a Covid-19-járvány legnagyobb vesztese. Az élelmiszerekre, italtermékekre és dohánytermékekre szakosodott üzletek forgalma a leginkább Csehországban csökkent. [17]

\section{Mi vár ránk a jövőben?}

A koronavírus elterjedésének az egyik legsúlyosabb következménye a vagyoni egyenlőtlenségek további erősödése. Az Oxfam nonprofit szervezet 2020. áprilisi becslése szerint a Covid-19járvány hatására közel félmilliárd ember, az emberiség 1/16-a kerülhet mélyszegénységbe. A hatalmas jövedelmi egyenlőtlenségeket mutatja az is, hogy elkövetkezendő 5 évben a dollármilliárdosok száma a világban várhatóan $27 \%$-kal fog gyarapodni, ezzel is tovább növelve a társadalom tagjai közötti egyenlőtlenséget. A leggyorsabb ütemben 6 ázsiai, 5 európai és 3 afrikai városban fog nőni az utóbb említett csoportba tartozók száma. A gazdagok számának növekedési üteme szerint felállított rangsorban a legjobb 10 között szerepel az Európai Unióba tartozó országok közül Svédország és Románia. Országunkban a dollármilliárdosok számát tekintve csupán 6\%-os növekedés várható. [2]

Az, hogy a jövőben meddig érezhetjük még az Európai Unióban és azon belül Magyarországon a Covid-19-járvány kedvezőtlen társadalmi, gazdasági és foglalkoztatási hatásait, bizonytalan. A Boston Consulting Group elemzése szerint a járvány legnagyobb csapása érintette a nemzetközi kereskedelmi forgalmat, és maradandó hatást gyakorolt rá. Még ha 2023-ra sikerül is visszaállítani a 2019-es állapotokat ezen a téren, egy biztos, a világgazdaság térképe jelentősen átrendeződik. Nemcsak számos nemzet gazdasága vált instabillá ezen időszak alatt, hanem a geopolitikai és az országon belüli feszültségek is megnövekedtek, melyek pozitív szintű megoldása még várat magára. [18] Ennek ellenére az EUROFOUND felmérése alapján a válaszadó EU lakosok 68\%-a volt optimista jövőjével kapcsolatban. A kutatás alapján a munkavállalóként dolgozó válaszadók 33\%-a bízik abban, hogy országa sikeresen leküzdi a Covid-19-járvány okozta nehézségeket, amit az is bizonyít, hogy a munkavállalók és munkáltatók rugalmasan viszonyultak a munkavégzés megváltozott formáihoz. [1] A Világgazdasági Fórum jelentése szerint Magyarország felkészültsége a következő évtizedre éppen csak elégséges. Egyedül csak a digitális infrastrukturális felkészültségünk kedvezőbb, mint a másik három visegrádi országé. A legfontosabb versenyképességi szempont, hogy a gazdaság szereplői számára biztosítva legyen a hosszútávú jövőkép. Ugyanis enélkül jelentősen csökken a gazdasági szféra kockázatvállalási hajlandósága, a befektetési kedve, amely kedvezőtlenül hat a gazdaság további alakulására. [19] A piaci szereplők optimizmusának megőrzéséhez a pandémia okozta kihívásokat figyelembe vevő, a munkaadókat és az alkalmazottakat támogató, az ország gazdasági újraindítását megcélzó állami intézkedések meghozatala elengedhetetlen. 
Minden esetre az biztos, hogy a járvány előtti munkaerőpiaci és gazdasági állapotokhoz nem tudunk visszatérni, és nem is kell, hiszen folyamatos változásban, fejlődésben, tanulásban vagyunk. Minden állam, és állampolgár megtapasztalta saját országának sebezhető pontjait, kitettségét. Úgy véljük, a felelős gondolkodás és cselekedet nemcsak egyénileg, hanem közösségileg, országok szintjén is felértékelődött, amit szem előtt kell tartanunk állandóan. Ami régen volt, az már elmúlt. A változásban lássuk meg a pozitív irányt, és e mentén tegyünk a jövőnkért.

\section{Hivatkozások}

[1] Ahrendt D. - Cabrita J. - Clerici E. - Hurley J. - Leončikas T. - Mascherini M. - Riso S. Sandor E. (2020): Living, working and Covid-19. Publications Office of the European Union. European Foundation for the Improvement of Living and Working Conditions, Luxembourg, 68 p. ISBN 978-92-897-2117-2, DOI:10.2806/467608

[2] Árgyelán Ágnes (2020): A koronavírus hatása: milliók süllyednek mélyszegénységbe, egy maréknyi ember meg sosem volt még ilyen gazdag. Portfólió. Letöltés ideje: 2021.03.11.

https://www.portfolio.hu/befektetes/20200815/a-koronavirus-hatasa-milliok-sullyednekmelyszegenysegbe-egy-mareknyi-ember-meg-sosem-volt-meg-ilyen-gazdag-444942

[3] Barabás T. - Czirók A. (2021): Távmunka vagy Home office? Munkajogi útmutató civil szervezetek és társadalmi vállalkozások számára. PILnet. Letöltés ideje: 2021. 07. 23.

https://www.pilnet.org/resource/tavmunka-a-covid-idejen-osszefoglalo-es-utmutato/

[4] Czirfusz Márton (2021): A COVID-19-válság és a térbeli munkamegosztás változásai Magyarországon. Területi Statisztika. 61. évf. 3. sz. 15 p. DOI: 10.15196/TS610303

https://www.ksh.hu/statszemle_archive/terstat/2021/2021_03/ts610303.pdf

[5] Csizmadia Norbert (2020): A jövő egy időre megváltozott- új világrend a koronavírusjárvány után. Világgazdaság. Letöltés ideje: 2021.03.11.

https://www.vg.hu/velemeny/elemzes/a-jovo-egy-idore-megvaltozott-uj-vilagrend-akoronavirus-jarvany-utan-2-3144142/

[6] EUROSTAT (2020): Fall in hours worked more visible for women in Q1 2020. Letöltés ideje: 2021.03.11.

https://ec.europa.eu/eurostat/web/products-eurostat-news/-/DDN-20200714-1

[7] EUROSTAT (2021): Prozent der zuhause arbeitenden Erwachsenen nach Geschlecht, Altersgruppe, Zahl der Kinder und Alter des jüngsten Kindes. Letöltés ideje: 2021.07. 31.

https://appsso.eurostat.ec.europa.eu/nui/show.do?dataset=lfst_hhwahchi\&lang=de

[8] Farkas Bence (2020): Hivatalos: Az IKT-szektor az ágazatok „Covid-álló” mellénye. Letöltés ideje: 2021.03.11.

https://blog.hiflylabs.hu/hu/2020/12/18/az-ikt-szektor-az-agazatok-covid-allo-mellenye/

[9] Herdon István (2020): Fontos elhatárolás: Távmunka vagy home office jellemezte a járványügyi veszélyhelyzetet?. Letöltés ideje: 2021. 07. 23.

https://arsboni.hu/fontos-elhatarolas-tavmunka-vagy-home-office-jellemezte-a-jarvanyugyiveszelyhelyzetet/\#_ftn9

[10] Központi Statisztikai Hivatal (2020a): Magyarország 2020, I-III. negyedév. Központi Statisztikai Hivatal kiadványtára. Letöltés ideje: 2021.03.11. 
https://www.ksh.hu/docs/hun/xftp/idoszaki/mone/20203/index.html

[11] Központi Statisztikai Hivatal (2020b): Munkaidő-csökkentés az alkalmazottak körében. Letöltés ideje: 2021.03.11.

https://www.ksh.hu/docs/hun/xftp/idoszaki/munkerohelyz/munkaidocsokk/index.html

[12] Központi Statisztikai Hivatal (2021a): A 15-74 éves foglalkoztatottak távmunkavégzésének alakulása. Letöltés ideje: 2021.03.11.

https://www.ksh.hu/docs/hun/xstadat/xstadat_evkozi/e_tavmunk9_17_02.html

[13] Központi Statisztikai Hivatal (2021b): A munkanélküliek száma. Letöltés ideje: 2021.03.11.

https://www.ksh.hu/docs/hun/xstadat/xstadat_evkozi/e_qlf022h.html

[14] Központi Statisztikai Hivatal (2021c): A munkanélküliek száma korcsoportok szerint, nemenként (2009-). Letöltés ideje: 2021.03.11.

https://www.ksh.hu/docs/hun/xstadat/xstadat_eves/i_mef017.html

[15] Központi Statisztikai Hivatal (2021d): Felértékelődött a távmunka a Covid19 árnyékában. Letöltés ideje: 2021. 07. 14. https://www.ksh.hu/docs/hun/xftp/idoszaki/koronavirustavmunka/index.html

[16] Lipták Katalin (2021): Maradj otthon, dolgozz otthon! - A koronavírus-járvány hatása a távmunkára Észak-Magyarországon, 2020. április. Területi Statisztika. 61. évf. 2. sz. 15 p. DOI: $10.15196 /$ TS610202

http://www.ksh.hu/statszemle_archive/terstat/2021/2021_02/ts610202.pdf

[17] Morais A. - Ivanov A. - Hristova B. - Ninov G. - Yanakieva N. - Slavcheva N. - Sanyal R. - Mladenov S. - Wu X. - Li Y. (2020): Retail bloom and gloom. Foresight 2021. ISI Emerging Markets Group.

[18] Pénzügyi Szemle (2020): Ötödével eshet vissza a nemzetközi kereskedelem a koronavírusjárvány miatt. Letöltés ideje: 2021.03.11.

https://www.penzugyiszemle.hu/tanulmanyok-eloadasok/otodevel-eshet-vissza-a-nemzetkozikereskedelem-a-koronavirus-jarvany-miatt

[19] Portfólió (2020): Mire számíthat Magyarország a járvány után? Lesújtó jelentés érkezett. Letöltés ideje: 2021.03.11. https://www.portfolio.hu/gazdasag/20201216/mireszamithat-magyarorszag-a-jarvany-utan-lesujto-jelentes-erkezett-461990\#

[20] Uzzoli A. - Kovács S. - Páger B. - Szabó T. (2021): A hazai COVID-19-járványhullámok területi különbségei. Területi Statisztika. 61. évf. 3. sz. 27 p. DOI: 10.15196/TS610302 https://www.ksh.hu/statszemle_archive/terstat/2021/2021_03/ts610302.pdf 